\title{
Evaluating Characteristics of Indigenous Chicken System with Flock Size Trends in a Participatory Research on Improved Management Practices in Kenya
}

\author{
Ndegwa, J. M, and Mead, R. \\ International and Rural Development Department (IRDD) and School of Applied Statistics \\ The University of Reading, PO Box 237 Reading, RG6 6AR, Reading, UK
}

Norrish, P, and Shepherd, D. D.

International and Rural Development Department (IRDD) and School of Applied Statistics

The University of Reading, PO Box 237 Reading, RG6 6AR, Reading, UK

Kimani, C. W, \& Wachira, A. M.

Kenya Agricultural Research Institute, National Animal Husbandry Research Centre PO Box 25, Naivasha, Kenya

Siamba, D. N.

Masinde Muliro University of Science and Technology,

Department of Biological Sciences

Joseph M Ndegwa (Corresponding author)

Email: j.n.ndegwa@reading.ac.uk; jndegwa93@yahoo.com; jmutitu603@gmail.com

Received: April 1, 2014 Accepted: April 18, 2014

doi:10.5296/jas.v3i2.6363 URL: http://dx.doi.org/10.5296/jas.v3i2.6363 


\section{Abstract}

This study investigates characteristics of indigenous chicken farms categorised on flock size patterns identified in a research involving 200 farmers in five regions in three counties (Nyandarua, Laikipia, Nakuru) in Kenya. Four villages were selected per region and 10 farms in each village. Training and sensitisation meetings, introduction of intervention options (Housing, Feed Supplementation, Vaccination and Deworming), implementation by farmers, and monitoring and evaluation were carried out. The farmers used own inputs in implementing the project interventions and recorded various project activities and outputs. The project was monitored over a span of five, 3-months long periods. Variation analysis was used to identify similarities and differences between 7 farm categories (groups) based on their differences on the levels of the following factors: (1) Average farm flock sizes at five different periods (2) Treatment characteristics (interventions) application - (housing, vaccination, de-worming, and supplementation) (3) Demography characteristics (total flock additions, total flock reductions, total unplanned reductions and total controlled reduction) and (4) Production characteristics (mean hatchability and egg production per hen per cycle based on predicted egg production). Results indicate there were significant differences between the groups. Almost all the flock size differences between farm groups were significant at 1 percent level. There was a rise in differences of the between and within groups mean squares from period 1 to 5 as a result of the flock sizes levels also increasing with period. The treatment characteristics application levels had little differences between groups but housing and feed supplementation had larger values than the other two characteristics. The treatments application differences not being significant could be a consequence of influence from the research team being more or less the same in all the farms. The demography characteristics, total addition and total reduction values were close to one another among the farm categories. These together with flock size levels had little influence from the research team but were mostly a reflection of individual farm's decision and activities. However, the production characteristics reflected more both the farmer's action and the hen potential. The group with the lowest flock size trends had production values close to those of other groups. This would suggest that low flock size level in a farm is not a reflection of poor production dynamics. The demographic characteristics differences between farms compare well with significant levels on flock size differences between farms shown earlier, especially the total additions, total reductions and total controlled reductions. There was no single significant difference among the groups on vaccination and production characteristics - mean hatchability and egg production. Production characteristics may have been more influenced by hen factors, which may not have been different among the different farm groups. The analysis of variance made it possible to validate the flock size classification using values of dissimilarity group index between farms.

Keywords: Indigenous chicken, Flock size, Demography, Treatments, Production, Variation analysis, Kenya.

\section{Introduction}

About $80 \%$ of the population in most of African region live in rural areas eking out a living 
from subsistence farming, often under very difficult climatic and economic conditions (Ndegwa, 2006), to meet household food requirements.

Indigenous chickens are among the many local resources available in rural areas which, if well managed, could ease the burden of the people. Over $90 \%$ of rural households keep and rear indigenous chicken in small flocks of about 20 birds (Ndegwa et. al., 1999; Mbugua, 1990; MOLD, 1990; Stotz, 1983). Many authors (Ndegwa, 2013; Gonsalves et al., 2005 Ndegwa et al., 2001b; Okong'o et al 1998; Tuitoyet et al; 1999; Kitalyi, 1998; FAO, 2008, 2010 and SA PPLPP, 2011 assert that indigenous chickens play a very significant role in rural livelihoods. In Kenya, and indeed in sub-Saharan Africa, indigenous chickens comprise over $70 \%$ of total poultry populations (MOLD, 1991; Ibe, 1990). They produce about $50 \%$ of the total eggs and over $80 \%$ of the poultry meat produced in many countries in sub-Saharan Africa (Ndegwa et al., 1998). Hence, there exists a potential for a local resource like indigenous chickens to turn around the misery that is the lives in rural areas as stated by Ndegwa, (2006) who also calls for an infrastructural and institutional support in research and development activities aimed at improving productivity at farm level.

Indigenous chicken system has generally been characterised by low productivity due to among other factors, poor management, inadequate and poor feeding regime, poor (or lack) of disease control measures, poor hygiene, inappropriate housing, negative attitudes, lack of technical knowledge and lack of institutional support in terms of policy and infrastructure (Ndegwa and Kimani, 1997). Importance of creating awareness and education is emphasised by Thieme et al (2014).

Proper harnessing of local resources of the poor people and their involvement in (the) research process can help bring about development of sustainable livelihoods and contribute to the fight on poverty alleviation in rural areas where the majority of the poor live (Ndegwa, 2006 and 2013; Gonsalves et al., 2005). Their number is mainly composed of women (Blair, 2000; Al-Sultan, 2001) who engage in subsistence agricultural activities as they struggle to survive and feed their families under often very hostile environments (Ndegwa et al., 2000, 1998a, 1999, 1997; Gueye, 2000a). Fanworth, et al., (2013) emphasise the fact that empowering women is key to poverty reduction as well as a key driver to agricultural productivity. According to FAO (2011), the agriculture sector is underperforming in many developing countries, and one of the key reasons is that women do not have equal access to the resources and opportunities they need to be more productive. FAO (2011) also recommends promoting gender equality and empowering women (Millennium Development Goal Schedule 3) in agriculture to win, sustainably, the fight against hunger and extreme poverty (MDG1).

Gonsalves, et al., (2005) write about new challenges to agricultural research and development that include shifting focus to less favourable environments, strengthening capacity of local farming communities to continuously learn and experiment ways of improving their agricultural livelihoods, research and development are no longer exclusive domain of scientist and that local stakeholders provide inputs to processes that find sustainable solutions. According to Okali et al., (1994) both farmers and researchers are involved at any or all 
points along a continuum of levels of participation.

There is however, little published peer-reviewed material regarding how benefits of participatory research are achieved in practice (Blackstock et al., 2007). This and other related studies by the same authors (Ndegwa et al., 2013, 2014) explore(s) and explain(s) importance of participatory research in practical terms. In a previous study by Ndegwa (2013) a demographic analysis used dissimilarity index analysis and identified seven distinct indigenous chicken farm groups categorised on flock size trends. The objective of the present study is to evaluate these farm groups' patterns and comparisons identifying similarities and differences between the groups. This will help to characterise indigenous chicken farms in Kenya and understand their character and potential for rural livelihoods. The aim was to generate and disseminate relevant information on improved production management practices for use by farmers and support services.

\section{Methodology}

This farmer participatory research was carried out between 1996 and 1999 to evaluate effects of improved management practices on performance of indigenous chickens at farm level. A total of twenty villages and 200 farmers were selected from 5 regions and 4 villages per region (Table 1) based on indication of willingness to participate. Ten farms were selected in each village. Training and sensitisation meetings were held with the selected farmers, their neighbours and extension personnel. This was followed by the introduction of treatments or intervention options (Feed supplementation, Housing, Vaccination, and Deworming) implementation by farmers, monitoring and evaluation by the main partners (farmers, extension and research). The project was monitored over a span of five, 3-months long periods. Monitoring was by a visit every three months to each farm to evaluate progress and confirm the farmer's records. This was also the time for more consultation and sharing of experiences.

The choice of this research design was influenced by the need to have a diverse representation of farmers participating in the project in order to collect information that might yield generalizable outcomes. The design involved:

-Selection of locations-5 regions in different Agro-Ecological Zones (aezs) and 4 villages per region. Each cluster has ten farmers and were based on land size as well as aezs criteria as shown in Table 1.

-Farmer selection-along a transect line in the cluster area and systematically sampled during baseline studies (Ndegwa et al. 1999). Main criteria, was willingness of the farmers to participate and carry out activities and have at least five indigenous chicken hens.

-Emphasis on use of farmer's own locally available resources and mobilisation of farmers in acquiring some external inputs jointly. Use of own local inputs is also emphasised by Sonaiya (1990).

-Training and sensitisation seminars-done per cluster in farmers' localities.

-Mode and plan of experimentation - individual farmer's decision. 
-Implementation of the research activities was entirely by the farmers to decide which intervention/s to take up among the options available.

-Monitoring and evaluation-daily by farmers taking records, and periodically by extension and researchers' visits to individual farms.

Table 1. Research locations with farm size, regional features and number of selected farmers

\begin{tabular}{|c|c|c|c|c|}
\hline Regions & Villages & $\begin{array}{l}\text { Average } \\
\text { Farm size } \\
\text { (acres) }\end{array}$ & Regional features & $\begin{array}{l}\text { No. } \\
\text { farmers }\end{array}$ \\
\hline $\begin{array}{l}\text { Laikipia } \\
\text { Ngarua }\end{array}$ & $\begin{array}{l}\text { Kinamba } \\
\text { Sipili } \\
\text { Cheleta } \\
\text { Ol Moran }\end{array}$ & $\begin{array}{l}2 \\
2.5 \\
10 \\
1\end{array}$ & $\begin{array}{l}\text { low potential semi-arid, poor infrastructure and frequent } \\
\text { livestock theft incidences }\end{array}$ & $\begin{array}{l}10 \\
10 \\
10 \\
10\end{array}$ \\
\hline OlKalou & $\begin{array}{l}\text { Olkalou } \\
\text { South } \\
\text { Passenga } \\
\text { Milangine } \\
\text { Kaibaga }\end{array}$ & $\begin{array}{l}2.5 \\
5 \\
2-4 \\
1\end{array}$ & $\begin{array}{l}\text { low to high potential and cold with frequent frost and water } \\
\text { logging incidences. Has impassable road network for } \\
\text { transportation during wet seasons. }\end{array}$ & $\begin{array}{l}10 \\
10 \\
10 \\
10\end{array}$ \\
\hline Bahati & $\begin{array}{l}\text { Munanda } \\
\text { Kabazi } \\
\text { Scheme } \\
\text { Wanyororo }\end{array}$ & $\begin{array}{l}2 \\
1.5 \\
3 \\
0.5\end{array}$ & $\begin{array}{l}\text { high potential with adequate rainfall and good soils for } \\
\text { agricultural activities, with land size ranging from } 5 \text { to } 0.25 \\
\text { acres per household and relatively good road network and } \\
\text { market opportunities }\end{array}$ & $\begin{array}{l}10 \\
10 \\
10 \\
10\end{array}$ \\
\hline Njoro & $\begin{array}{l}\text { Njokerio } \\
\text { Gichobo } \\
\text { Piave } \\
\text { Likia } \\
\end{array}$ & $\begin{array}{l}0.25 \\
5 \\
2.5 \\
1 \\
\end{array}$ & $\begin{array}{l}\text { high to medium potential with good to poor road network and } \\
\text { market opportunities. }\end{array}$ & $\begin{array}{l}10 \\
10 \\
10 \\
10\end{array}$ \\
\hline Naivasha & $\begin{array}{l}\text { Karate } \\
\text { Maraigushu } \\
\text { Karai } \\
\text { Mirera } \\
\end{array}$ & $\begin{array}{l}1.5 \\
2.5 \\
5 \\
1 \\
\end{array}$ & $\begin{array}{l}\text { low potential, porous volcanic soils of high infiltration. Good } \\
\text { to poor road network especially during wet periods villages }\end{array}$ & $\begin{array}{l}10 \\
10 \\
10 \\
10\end{array}$ \\
\hline $\begin{array}{l}5 \\
\text { (Total) }\end{array}$ & $\begin{array}{l}20 \\
\text { (Total }(\end{array}$ & $\begin{array}{l}2.65 \\
\text { (Mean) }\end{array}$ & & $\begin{array}{l}200 \\
\text { (Total) }\end{array}$ \\
\hline
\end{tabular}

The demography analysis (Ndegwa, 2013) had used dissimilarity index as a tool for differentiating and confirming groups classified from among individual farms through to village clusters and on to regional groups and lastly down to the final farms grouping. One hundred and seventy three farms with varying flock size trends over 5 periods were reduced first into 48 village groups and 12 outliers. The village groups were further classified into a smaller number of 25 regional groups and 9 outliers. Finally, a further elaboration of classification reduced regional groups into seven final groups and 3 outliers (Table 2) each with a distinct characteristic pattern defining it.

The objective of the present study is to evaluate these 7 farm groups' patterns and comparisons identifying similarities and differences between the groups as influenced by 
application of the improved management practices. This will help to characterise indigenous chicken system in Kenya and understand its potential for rural livelihoods. This will aid in generating and disseminating relevant information on improved production management practices for use by farmers and support services.

These final groups were used in the present study investigating for their differences on the levels of the following factors:

- Average farm flock sizes at five different periods

- Treatment characteristics (housing, vaccination, de-worming, and supplementation)

- Demography characteristics (total flock additions, total flock reductions, total unplanned reductions and total controlled reduction)

- Production characteristics (mean hatchability and egg production per hen per cycle based on predicted egg production).

Table 2. Distribution of farms among the identified groups in five regions

\begin{tabular}{|c|r|r|r|r|c|}
\hline Final Farm Group & \multicolumn{5}{|c|}{ Region } \\
\cline { 2 - 6 } & 1 & 2 & 3 & 4 & 5 \\
\hline 1 & 13 & 15 & 11 & 13 & 23 \\
\hline 2 & 10 & 10 & 16 & 3 & 11 \\
\hline 3 & 2 & 0 & 2 & 7 & 3 \\
\hline 4 & 1 & 3 & 0 & 3 & 0 \\
\hline 5 & 6 & 2 & 0 & 0 & 0 \\
\hline 6 & 4 & 3 & 4 & 1 & 1 \\
\hline 7 & 1 & 0 & 2 & 0 & 2 \\
\hline 8 (outlier) & 0 & 0 & 1 & 0 & 0 \\
\hline 9 (outlier) & 0 & 0 & 0 & 1 & 0 \\
\hline 10 (outlier) & 0 & 0 & 0 & 1 & 0 \\
\hline Total farms & 37 & 33 & 36 & 27 & 40 \\
\hline
\end{tabular}

The investigations involved analysis of variance done only for the seven final farm groups excluding the three outliers and used standard general linear models (GLM) statistical procedures of SAS (1995). To check for significant differences between groups, a two-way Duncan-Dunnett sample test was done to separate different means. The analysis of the average flock sizes of the final groups was done at each of the five periods for the treatment and demography characteristics. Totals for the five periods were used while in the case of the production characteristics, the average mean hatchability and egg production per hen-cycle were used. The outlier farms were left out due to the obvious distortion of information they were likely to introduce.

\section{Results and Discussion}

Fig 1 provides indigenous chicken farm categories with levels and trends of their flock size in over five periods. Farm group 1 consists of farms characterised by a flock size trend starting from about 15 rising steadily to 25 birds per farm. Farm group 2 consists of farms characterised by a flock size trend starting from 20 and rising steadily over the periods to 35 
birds per farm. Farm group 3 consists of farms characterised by a flock size trend starting from about 20 birds rising more sharply mid period to a high of about 50 birds per farm. Farm group 4 consists of farms characterised by a flock size trend that starts on a high of 30 birds rising sharply to a peak of 60 birds per farm. Farm group 5 consists of farms characterised by an unusual trend that starts from a high of about 30 birds dropping steadily to about 15 birds per farm. Farm group 6 consists of farms characterised by a steady flock size trend averaging about 40 birds per farm in the five periods of observation. Farm group 7 consists of farms characterised by low flock size trend with an average of about 10 birds per farm in all the five periods of observation.

\section{FLOCK SIZ⿱一⿻上丨匕 OF FARM GROUPS EXCLUDING OTLS PLOTTED AGAINST PERIOD}

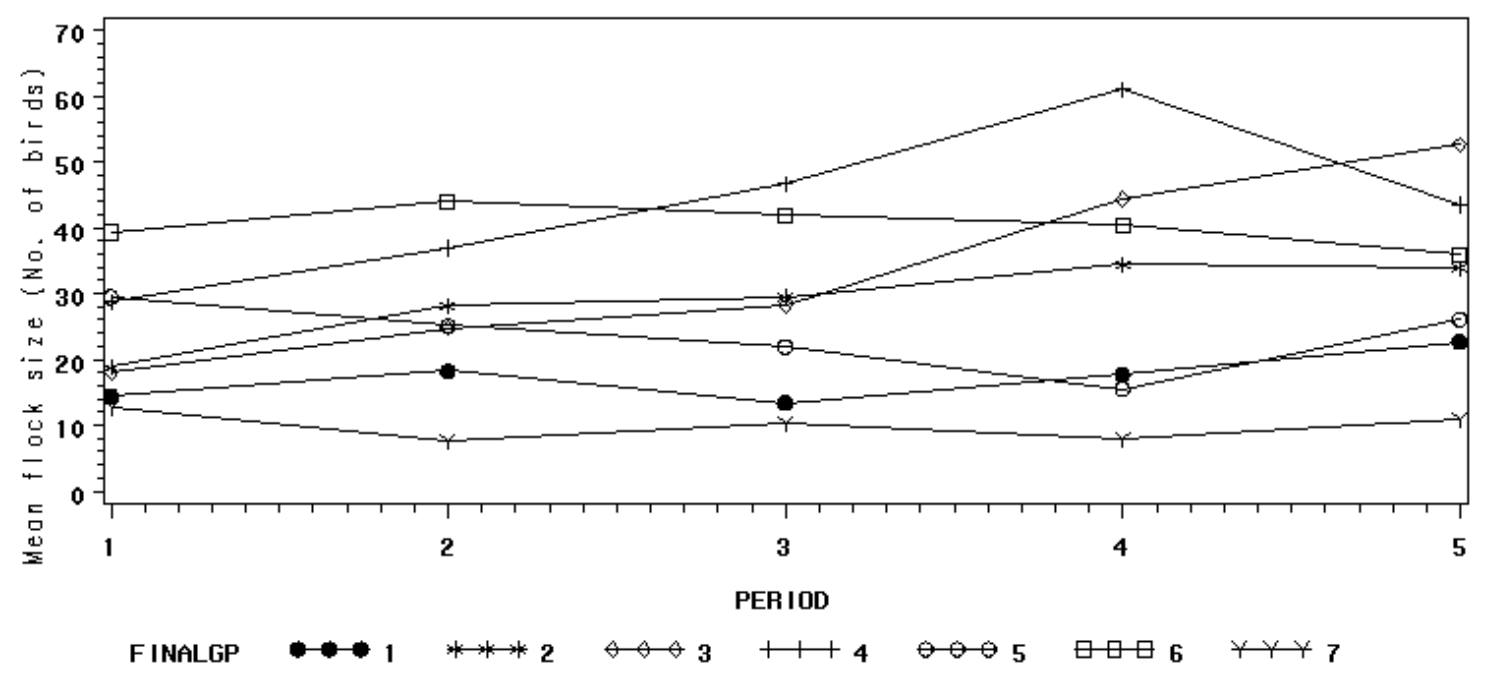

FINALGP=3, 4, 5, 6, 7 make up a cluster of groups with smaller number of farms

Figure 1. Flock size trends of seven groups of Kenyan indigenous chicken farms

The seven groups provides a snapshot of characteristics and behaviour of Kenyan small scale farms in regard to production and use of indigenous chicken as a livelihood strategy.

Table 3 shows a summary of the analysis of variance model or between groups mean square on 6 degrees of freedom for flock size because there were only seven final farm groups. The three outliers were excluded to avoid distortion of statistical analysis result by exaggerating mean values of the groups. The analysis was done for each period.

Table 3. Analysis of variance for average flock size among 7 final farm groups in five periods

\begin{tabular}{|c|c|c|c|}
\hline Period & Between/Model MS (df) & Within/Error MS (df) & F-ratio \\
\hline 1 & $1513(6)$ & $28(166)$ & 54.5 \\
\hline 2 & $1915(6)$ & $32(166)$ & 60.1 \\
\hline 3 & $3208(6)$ & $47(166)$ & 68.7 \\
\hline 4 & $4462(6)$ & $61(166)$ & 73.0 \\
\hline 5 & $2428(6)$ & $94(164)$ & 26.9 \\
\hline
\end{tabular}

${ }^{1}$ df: the degrees of freedom of error MS in period 5 reduced by removal of 2 farms with flock sizes values of zero and 3. 


\section{Mll Macrothink}

Overall, the results from the analysis indicate significant differences between the farm groups hence confirming the distinctness of the groups as categorised, as well as affirming the validity of our classification procedures using the dissimilarity index values (Ndegwa, 2006). Only the comparisons $1 \mathrm{v} 5,1 \mathrm{v} 7$ and $2 \mathrm{v} 3$ were non-significant twice in five periods. No comparison was non-significant more than twice. In case of groups 1 and 5, both had close flock size values at periods 4 and 5. Groups 1 and 7 were close to each other flock size-wise at periods 1 and 3, as was the case with groups 2 and 3 .

Table 4 shows significance comparisons of flock sizes between the farm groups in periods 1 to 5. Almost all the differences were significant at 1 percent level. There was a rise in differences of the between and within groups mean squares from period 1 to 5 as a result of the flock sizes levels also increasing with period. This is better shown using pair-wise comparison standard errors for farm group pairs with large differences in their number of farms provided by Table 5 which also includes the flock size differences between the pairs.

The standard errors (SE) provide the precision with which the difference is determined, and as such are standard errors of the difference. The larger they are, the less the precision and hence the lower the significant level of the difference. This implies that pairs with similar differences might have different significant levels depending on their SE values, as was the case between the pairs, 1v2 and 1v3. The differences, SE, and confidence interval width all increased with period.

Table 4. Significance comparisons between groups on average flock sizes in period 1-5

\begin{tabular}{|c|c|c|c|c|c|}
\hline \multirow[t]{2}{*}{ Group Comparison } & \multicolumn{5}{|c|}{ Period significant level $^{1}$} \\
\hline & 1 & 2 & 3 & 4 & 5 \\
\hline $1 \mathrm{v} 2$ & $* * *$ & $* * *$ & $* * *$ & $* * *$ & $* * *$ \\
\hline $1 v 3$ & * & $* * *$ & $* * *$ & $* * *$ & $* * *$ \\
\hline $1 \mathrm{v} 4$ & $* * *$ & $* * *$ & $* * *$ & $* * *$ & $* * *$ \\
\hline $1 v 5$ & $* * *$ & $* *$ & $* * *$ & & \\
\hline $1 \mathrm{v} 6$ & $* * *$ & $* * *$ & $* * *$ & $* * *$ & $* * *$ \\
\hline $1 v 7$ & & $* * *$ & & * & $*$ \\
\hline $2 \mathrm{v} 3$ & & $*$ & & $* * *$ & $* * *$ \\
\hline $2 \mathrm{v} 4$ & $* * *$ & $* * *$ & $* * *$ & $* * *$ & $*$ \\
\hline $2 v 5$ & $* * *$ & & $* *$ & $* * *$ & $*$ \\
\hline $2 \mathrm{v} 6$ & $* * *$ & $* * *$ & $* * *$ & $*$ & \\
\hline $2 \mathrm{v} 7$ & $*$ & $* * *$ & $* * *$ & $* * *$ & $* * *$ \\
\hline $3 v 4$ & $* * *$ & $* * *$ & $* * *$ & $* * *$ & $*$ \\
\hline $3 v 5$ & $* * *$ & & $*$ & $* * *$ & $* * *$ \\
\hline $3 \mathrm{v} 6$ & $* * *$ & $* * *$ & $* * *$ & & $* * *$ \\
\hline $3 \mathrm{V7}$ & $*$ & $* * *$ & $* * *$ & $* * *$ & $* * *$ \\
\hline $4 \mathrm{v} 5$ & & $* * *$ & $* * *$ & $* * *$ & $* *$ \\
\hline $4 \mathrm{v} 6$ & $* * *$ & $*$ & & $* * *$ & \\
\hline $4 \mathrm{V7}$ & $* * *$ & $* * *$ & $* * *$ & $* * *$ & $* * *$ \\
\hline $5 \mathrm{v} 6$ & $* * *$ & $* * *$ & $* * *$ & $* * *$ & $*$ \\
\hline $5 \vee 7$ & $* * *$ & $* * *$ & $* *$ & & $*$ \\
\hline $6 v 7$ & $* * *$ & $* * *$ & $* * *$ & $* * *$ & $* * *$ \\
\hline
\end{tabular}

${ }^{1}$ Period significant level: 3 stars refers to significant level at $0.1 \%, 2$ stars, $1 \%$ and 1 star at $5 \%$ 
Table 5. Pairwise standard errors comparisons on flock size of large farm groups at 5 periods

\begin{tabular}{|c|c|c|c|c|c|c|c|c|c|c|c|c|c|c|c|c|}
\hline \multirow{3}{*}{$\begin{array}{l}\text { Group } \\
\text { Pairs }\end{array}$} & \multirow{3}{*}{$\begin{array}{c}\text { No of } \\
\text { farms } \\
(\mathrm{n} 1, \mathrm{n} 2)\end{array}$} & \multicolumn{15}{|c|}{ Period $^{1}$} \\
\hline & & \multicolumn{3}{|c|}{$1\left(\mathrm{~s}^{2}=28\right)$} & \multicolumn{3}{|c|}{$2\left(s^{2}=32\right)$} & \multicolumn{3}{|c|}{$3\left(s^{2}=47\right)$} & \multicolumn{3}{|c|}{$4\left(s^{2}=61\right)$} & \multicolumn{3}{|c|}{$5\left(\mathrm{~s}^{2}=94\right)$} \\
\hline & & Diff & $\mathrm{SE}$ & CIW & Diff & SE & CIW & Diff & SE & CIW & Diff & SE & CIW & Diff & SE & CIW \\
\hline $1 \mathrm{v} 2$ & 76,50 & 4.3 & 0.96 & 3.8 & 9.9 & 1.03 & 4.1 & 16.1 & 1.24 & 4.9 & 16.7 & 1.42 & 5.6 & 11.2 & 1.76 & 7.0 \\
\hline $1 \mathrm{v} 3$ & 76,13 & 3.6 & 1.59 & 6.2 & 6.5 & 1.70 & 6.7 & 14.8 & 2.06 & 8.1 & 26.8 & 2.34 & 9.3 & 30.0 & 2.91 & 11.5 \\
\hline $1 \mathrm{v} 4$ & 76,7 & 14.3 & 2.09 & 8.2 & 18.7 & 2.23 & 8.8 & 33.2 & 2.71 & 10.7 & 43.3 & 3.08 & 12.2 & 20.9 & 3.83 & 15.1 \\
\hline $2 \mathrm{v} 3$ & 50,13 & 0.78 & 1.65 & 9.63 & 3.4 & 1.76 & 6.8 & 1.3 & 2.13 & 12.4 & 10.0 & 2.43 & 9.6 & 18.8 & 3.02 & 11.9 \\
\hline $2 \mathrm{v} 4$ & 50,7 & 10.0 & 2.13 & 8.4 & 8.8 & 2.28 & 9.0 & 17.2 & 2.77 & 10.6 & 26.6 & 3.15 & 12.5 & 9.7 & 3.91 & 15.4 \\
\hline $3 \mathrm{v} 4$ & 13,7 & 10.8 & 2.48 & 9.8 & 12.2 & 2.65 & 10.4 & 18.5 & 3.21 & 12.6 & 16.5 & 3.66 & 14.5 & 9.1 & 4.54 & 17.9 \\
\hline
\end{tabular}

${ }^{1}$ Period: Diff $=$ difference in flock size between pairs of final groups; $\mathrm{SE}=$ standard error; $\mathrm{CIW}=$ confidence interval width

Summaries of the treatment (Total Housing, Total Vaccination, Total Deworming and Total Supplementation), demography (Total Addition, Total Reduction, Total Unplanned Reduction and Total Controlled Reduction), and production (Mean Hatchability and Predicted Eggs/hen/cycle) parameters mean values for the farm groups are given in Tables 6, 7, and 8 respectively.

Table 6. Average levels of treatment characteristics and number of farms in each final farm group category.

\begin{tabular}{|c|c|c|c|c|c|}
\hline Final Farm Group & No of farms & Total Housing & Total Vaccination & Total Deworming & Total Supplementation \\
\hline 1 & 73 & 2.82 & 1.21 & 1.94 & 3.67 \\
\hline 2 & 48 & 2.56 & 1.10 & 1.80 & 4.06 \\
\hline 3 & 13 & 3.08 & 1.54 & 1.77 & 3.85 \\
\hline 4 & 8 & 4.25 & 1.25 & 2.0 & 3.87 \\
\hline 5 & 8 & 2.25 & 1.75 & 2.37 & 3.75 \\
\hline 6 & 14 & 3.0 & 1.36 & 2.14 & 3.86 \\
\hline 7 & 5 & 1.6 & 1.0 & 3.2 & 4 \\
\hline 8 & 1 & 5 & 2 & 5 & 5 \\
\hline 9 & 1 & 5 & 2 & 3 & 4 \\
\hline 10 & 1 & 4 & 2 & 2 & \\
\hline
\end{tabular}

NB: Values are average totals in each farm in 5 periods for each character.

The number of farms used in the investigation with egg production parameters, was less than for the other categories of characteristics mainly because not all farms whose flock size information was available had also records on egg production.

The treatment characteristics application levels (Table 6) had little differences between groups but housing ( 3 out of 5 periods) and feed supplementation ( 4 out of 5 periods) had larger application values than the other two characteristics. Treatment characteristics were much influenced by our intervention as a research team and were more or less uniformly applied due probably to the near equal coverage access of all participating farmers to our 
information and expertise.

The demography characteristics, total addition and total reduction values (Table 7) were close to one another among the groups. Inevitably, the flock sizes in period 1 would also be expected to be close to flock sizes at the end of period 5 (start of period 6), which has not been included in our presentation but was used to determine demography values in period 5 . For instance, in the case of the farm group 1, the difference between the two, which is 4.2, added to flock size value of 15 in period 1, is 19.2. Total controlled reduction representing real benefit to farmers ranged from 29-52 birds per form over the five periods. This table shows production characteristics and behaviour of various farm categories on utilisation of indigenous chicken as a livelihood strategy. Despite clear differences in flock size levels, the farm groups appears similar in the way they produce and benefit from indigenous chicken looking at the total additions and total controlled reductions.

Table 7: Average levels of demography characteristics and number of farms in each final farm group category.

\begin{tabular}{|c|c|c|c|c|c|}
\hline $\begin{array}{c}\text { Final Farm } \\
\text { Group }\end{array}$ & $\begin{array}{c}\text { No of } \\
\text { farms }\end{array}$ & $\begin{array}{c}\text { Total } \\
\text { Addition }\end{array}$ & $\begin{array}{c}\text { Total } \\
\text { Reduction }\end{array}$ & $\begin{array}{c}\text { Total Unplanned } \\
\text { Reduction }\end{array}$ & $\begin{array}{c}\text { Total Controlled } \\
\text { Reduction }\end{array}$ \\
\hline 1 & 73 & 55.1 & 50.9 & 17.7 & 33.4 \\
\hline 2 & 48 & 62.4 & 53.8 & 18.8 & 35.0 \\
\hline 3 & 13 & 72.5 & 53.4 & 15.6 & 57.9 \\
\hline 4 & 8 & 68.3 & 68.1 & 16.1 & 45.6 \\
\hline 5 & 8 & 66.2 & 72.9 & 27.3 & 28.8 \\
\hline 6 & 14 & 47.7 & 68.8 & 17.1 & 173 \\
\hline 7 & 5 & 52.0 & 51.8 & 23.0 & 172 \\
\hline 9 (outlier) & 1 & 195 & 199 & 26 & 164 \\
\hline 10 (outlier) & 1 & 157 & 198 & 26 & 14 \\
\hline
\end{tabular}

NB: Values are totals in 5 periods for each character.

The demography characteristics had little influence from the research team but were mostly a reflection of individual farm decision and activities. On the other hand, the production characteristics (Table 8) reflected more both the farmer's action and the hen potential. Mean hatchability ranged from $65 \%$ (farm group 2) to $76 \%$ (farm group 7) while egg production ranged from 21-24 predicted eggs/hen/cycle. These hatchability values compare well with results from other authors investigating this characteristic among indigenous chicken (Albrecht, 2011; Abiola et al., 2008; Asuquo, et al., 1992).

Table 8. Average values of production characteristics among 7 final groups and outlier farm 8

\begin{tabular}{|c|c|c|c|}
\hline Final Farm Group & Number of farms & Mean Hatchability & Predicted Eggs/hen/cycle \\
\hline 1 & 48 & 70.3 & 21.8 \\
\hline 2 & 36 & 68.3 & 22.7 \\
\hline 3 & 9 & 71.4 & 21.1 \\
\hline 4 & 6 & 73.5 & 23.5 \\
\hline 5 & 5 & 73.6 & 21.3 \\
\hline 6 & 8 & 71.9 & 20.9 \\
\hline 7 & 3 & 74.6 & 20.5 \\
\hline 8 & 1 & 85.7 & 15.5 \\
\hline
\end{tabular}




\section{Ml Macrothink}

Journal of Agricultural Studies

ISSN 2166-0379

2015, Vol. 3, No. 2

The farm group 7 with the lowest flock size trends had production values close to those of other groups. This would suggest that low flock size level in a farm is not a reflection of poor production dynamics.

Table 9 provides the between and within mean squares with $\mathrm{F}$ values from the analysis of variance on treatment, demography and production characteristics differences of the final groups. The pair-wise significant comparisons for these characteristics are shown in Table 10.

Hence, less variation between farms would be expected, and in practice, there were only four significant differences for housing, 3 for deworming, 1 for supplementation. On the other hand, the demography characteristics, total addition, total reduction and total controlled reduction had significant differences between groups.

Table 9. Analysis of variance summary with treatment, demography and production characteristics

\begin{tabular}{|c|c|c|c|}
\hline Characteristic & $\begin{array}{c}\text { Between Groups / Model Mean } \\
\text { squares (df) } \\
\end{array}$ & $\begin{array}{l}\text { Within Groups / Error Mean } \\
\text { Squares (df) }\end{array}$ & F-ratio \\
\hline \multicolumn{4}{|l|}{ 1. Treatments: } \\
\hline Housing & $5.1(6)$ & $4.8(162)$ & 1.1 \\
\hline Vaccination & $0.78(6)$ & $1.3(162)$ & 0.6 \\
\hline Deworming & $1.84(6)$ & $1.4(162)$ & 1.31 \\
\hline Supplementation & $0.78(6)$ & $1.3(162)$ & 0.6 \\
\hline \multicolumn{4}{|l|}{ 2. Demography: } \\
\hline Total Addition & $1194(6)$ & $281(162)$ & 4.2 \\
\hline Total Reduction & $1326(6)$ & $277(6)$ & 4.8 \\
\hline $\begin{array}{l}\text { Total Unplanned } \\
\text { Reduction }\end{array}$ & $156(6)$ & $93(162)$ & 1.7 \\
\hline $\begin{array}{l}\text { Total Controlled } \\
\text { Reduction }\end{array}$ & $1155(6)$ & $185(162)$ & 6.25 \\
\hline \multicolumn{4}{|l|}{ 3. Production: } \\
\hline Mean Hatchability & $58(6)$ & $124(108)$ & 0.47 \\
\hline Predicted Eggs & $8.7(6)$ & $7.9 \quad(99)$ & 0.47 \\
\hline
\end{tabular}




\section{Macrothink}

Journal of Agricultural Studies

ISSN 2166-0379

2015, Vol. 3, No. 2

Table 10. Pairwise standard errors comparisons ${ }^{1}$ of farm groups on treatment and production parameters

\begin{tabular}{|c|c|c|c|c|c|c|c|}
\hline \multirow[t]{2}{*}{ Group Pairs } & \multicolumn{3}{|c|}{ Treatments } & \multicolumn{4}{|c|}{ Demography } \\
\hline & Housing & Deworming & Supplementation & $\begin{array}{c}\text { Total } \\
\text { Additions }\end{array}$ & $\begin{array}{c}\text { Total } \\
\text { Reductions }\end{array}$ & $\begin{array}{l}\text { Total Unplanned } \\
\text { Reductions }\end{array}$ & $\begin{array}{l}\text { Total Controlled } \\
\text { Reductions }\end{array}$ \\
\hline $1 \mathrm{v} 2$ & & & $*(\mathrm{p}=0.07)$ & $*$ & & & \\
\hline $1 v 3$ & & & & $* *$ & & & \\
\hline $1 \mathrm{v} 4$ & $*(\mathrm{p}=0.08)$ & & & $*$ & $*$ & & $* * *$ \\
\hline $1 \mathrm{V5}$ & & & & $\mathrm{p}(0.10)$ & $* * *$ & $*$ & $*$ \\
\hline $1 \mathrm{v} 6$ & & & & & $* * *$ & & $* * *$ \\
\hline $1 \mathrm{v} 7$ & & $*$ & & & & & \\
\hline $2 v 3$ & & & & $*$ & & & \\
\hline $2 \mathrm{v} 4$ & $*$ & & & & $*$ & & $* *$ \\
\hline $2 v 5$ & & & & & $* *$ & $*$ & $*$ \\
\hline $2 \mathrm{v} 6$ & & & & $* *$ & $* *$ & & $* * *$ \\
\hline $2 \mathrm{v} 7$ & & $*$ & & & & & \\
\hline $3 v 4$ & & & & & $*$ & & $*$ \\
\hline $3 v 5$ & & & & & $*$ & $*$ & \\
\hline $3 \mathrm{v} 6$ & & & & $* * *$ & $*$ & & $*$ \\
\hline $3 v 7$ & & $*$ & & $*$ & & & \\
\hline $4 \mathrm{v} 5$ & $* \mathrm{p}(0.0697)$ & & & & & $*$ & \\
\hline $4 \mathrm{v} 6$ & & & & & & & \\
\hline $4 \mathrm{v} 7$ & $*$ & & & & & & $* *$ \\
\hline $5 v 6$ & & & & $*$ & & $*$ & \\
\hline $5 v 7$ & & & & & $*$ & & $*$ \\
\hline $6 \mathrm{v} 7$ & & $*(\mathrm{p}=0.09)$ & & & $*$ & & $* *$ \\
\hline
\end{tabular}

NB: $p$ is the probability associated with the F-statistics level of significance and the smaller the value the higher the significance level. It is advisable to indicate value of $\mathrm{p}$ for single star levels (>5\%). ${ }^{1}$ significant level: 3 stars refers to significant level at $0.1 \%, 2$ stars, $1 \%$ and 1 star at $5 \%$

As was the case with flock sizes levels, the demography characteristics, total addition, total reduction and total controlled reduction were a manifestation of individual farmer's management decisions. Farmers would have had little influence on the total unplanned reduction. In the significant levels comparison of final farm groups (Table 10), there was no single significant difference among the groups on vaccination and production characteristics-mean hatchability and egg production. Production characteristics may have been more influenced by hen factors, which may not have been different among the different farm groups.

The flock demography dynamic characteristics were under direct influence of farmers' actions and these varied from farm to farm which might explain the reason behind the observed effects. The demographic characteristics differences between farms compare well with significant levels on flock size differences between farms shown earlier, especially the total additions, total reductions and total controlled reductions.

In classification of groups using flock size values, village average would be unsuitable when 
identified groups are distinctly different as was the case here.

The analysis of variance made it possible to validate the flock size classification using values of dissimilarity group index between farms.

The flock sizes levels and demography characteristics were a manifestation of the individual farmer's management decisions, which varied from one farm to another. On the other hand, the treatments application levels were more than anything else influenced by the research team and were almost similar among the participating farmers. These characteristics were much influenced by the research team and were more or less uniformly applied due probably to the near equal coverage access of all participating farmers to information and expertise provided. The production characteristics values had much influence from hen factors.

The seven farm groups provides a snapshot of characteristics and behaviour of Kenyan small scale farms in regard to production and use of indigenous chicken as a livelihood strategy. Hence this local resource should be harnessed as a strategy to bring about development of sustainable livelihoods and contribute to the fight on poverty alleviation in rural areas.

\section{Acknowledgement}

I would like to extend my gratitude first to my supervisor, Professor Roger Mead at the school of Applied Statistics, University of Reading UK. Much appreciation is also extended to my other supervisors at the department of International and Rural Development (IRDD), Dr Patricia Norrish and Derek Shepherd, my great mentors at the University of Reading. Many thanks also to other people at both the Applied Statistics and IRDD for their great support and encouragement. I would also wish to thank the Director, Kenya Agricultural Research Institute and the Centre Director, KARI, Naivasha, and the staff at both the headquarter and Naivasha, for their support and great understanding. Special mention is deserved for my colleagues at Naivasha with whom we executed this farmer participatory study. Special thanks to my former colleagues, Catherine Kimani, Dr Donald Siamba and Dr Anne Wachira for their contribution. Many other colleagues at KARI and all the extension friends in all the locations we visited are greatly acknowledged for their contributions and enthusiasm led by Gathu Munga. I'm grateful to Mr J. Kiptarus and Mrs C. Ngunjiri at the Ministry of Livestock Development Headquarters Nairobi for their cooperation and partnership in many poultry activities across our country Kenya.

\section{References}

Abiola, S. S., Meshioye, O. O., Oyerinde, B. O., \& Bamgbose, A.M. (2008). Effect of egg size on hatchability of broiler chicks. Arch. Zootech., 57(217): 83-86.

Albrecht, H. N. (2011). Reproductive soundness and egg quality in chickens selected for low and high antibody response, M.Sc. Thesis, Faculty of the Virginia Polytechnic Institute and State University, Blacksburg, V.A: 5-32.

Asuquo, B. O., Okon, B., \& Eking, A. A., (1992). Quality parameters of Isa Brown and Nigerian local chicken eggs. Nigerian Journal of Animal Production, 19” 1-5. 
Fanworth, C., Sudell, M., Nzioki, A., Shivutse, V., \& Dan, M., 2013 (eds).Transforming gender relations in agriculture in Sub-Saharan Africa.Swedish International Agricultural Network Initiative (SIAN), Stockhom Environmental Institute, Sweden.

FAO, (2008). Poultry in the 21st century: Avian influenza and beyond. O. Thieme and D Pillings eds. Proceedings of International Poultry Conference held 5-7 November, Bangkok, FAO Animal Production and Health Proceedings, No. 9. Rome FAO. (Available at ftp://ftp.fao.org/docrep/fao/011/i0323e/i0323e.pdf).

FAO, (2010). Smallholderpoultyr production: Livelihoods, food security and socio-cultulral significance. K. N. Kryger, K. A. Thonsen, M. A. Whyte and M. Dissing. (available at www.fao.org/docrep/013/al.674e/al674e00.pdf)

FAO, (2011). Women in Agriculture: Closing the gender gap for development. The state of food and agriculture 2010-2011. FAO of UN, Rome, Italy. [Online] Available: http://www.fao.org/publication/sofa/2010-11/en.

Gonsalves, J., Becker, T., Braun, A., Camplan, D., Chavev, H., Fajber, E., Kapiriri, M., Rivacamirade, J., Vernooy, M. (edts) 2005. Participatory research and development for sustainable agriculture and natural resource management: A sourcebook Vol 1: Understanding research and development. International Potato Centre-Users' Perspectives with Agricultural Research and Development, Laguna, Philippines and International Development Research Centre, Ottawa, Canada.

Gueye, E. F. (2000). The role of family poultry in poverty alleviation, food security and the promotion of gender equality in rural Africa. Outlook on Agriculture. 29(2), 129-136.

Kitalyi, A. J. (1998). Village chicken production system in rural Africa: Household food security and gender issues. FAO Animal Production and Health Paper, 142. Rome, FAO. [Online] Available: ww.fao.org/docrep/003/w8989e/w8989e00.htm

Ndegwa, J. M. (1992a). Digestibility and Metabolic Energy determination of ground and unground sesame (Sesamum indicum) seeds in broiler diets. Msc Thesis, 1992, Wageningen Agricultural University, Wageningen, The Netherlands.

Ndegwa, J. M. (1992b). Use of sesame seeds (Sesamum indicum) in broiler feeds. Proceedings, IX World Poultry Congress - Young professionals program. October 1992. Amsterdam, The Netherlands.

Ndegwa, J. M., Mbugua, H. C. W., Owango, M. O., \& Mburu, B. M. (eds) (1994). Proceedings of second Poultry Research Priority setting Workshop. Naivasha, 15-16 November. Kenya Agricultural Research Institute.

Ndegwa, J. M., \& Kimani, C. W. (1997). Rural poultry production in Kenya: Research and development strategies. In: Proceedings of 5th Kenya Agricultural Research Institute (KARI) scientific conference, October, 1996. KARI, Nairobi.

Ndegwa, J. M., Tchombe, T., Kabuage, L. W., Mukkibi-Muka, G., \& Kosgey, I. S., (1998). Improvement of indigenous poultry production in Sub-Saharan Africa. A paper presented at 
the International Course on Intensive Poultry Production held at the Centre for International Agricultural Development Co-operation (CINADCO). Kibbutz Shefayim, 4 March - 1 April 1998. P.O. Box 7011, Tel-Aviv, Israel.

Ndegwa, J. M., Kimani, C. W., Siamba, D. N., Mburu, B. M., Mukisira, E. A., \& de Jong, R., (1999). Characteristics of rural poultry production in different agro-ecological zones in Kenya. In Proceedings of the 6th biennial Kenya Agricultural Research Institute (KARI) scientific conference 9 - 13 November 1998, pp 540 - 547. Nairobi, Kenya. KARI.

Ndegwa, J. M., Norrish, P. Mead, R., Kimani, C. W., Wachira, A. M., (2000). A research process and methodology focusing on indigenous Kenyan chickens. A paper presented at the Symposium of the International Network for Family Poultry Development (INFPD) at the XXI World's Poultry Congress. 20-24 August, 2000. Montreal, Canada. [Onl;ine] Available:http//www.fao.org//ag/againfo/subjects/en/infd/documents/newsletters/Infd111.pdf and http://www.fao.org/docrep/019/aq634e/aq634e.pdf - The Bangladesh model and other experiences in family poultry development. International Network for Family Poultry Development (INFPD) May-July 2002.

Ndegwa, J. M., Norrish, P. Mead, R., Kimani, C. W., Wachira, A. M. (2001a). The growth performance of Kenyan indigenous chicken fed diets containing different levels of protein during rearing. Tropical Animal Health and Production 33 (5), 441-448.

Ndegwa, J. M ., D. D. Shephered1, Norrish, P.1 Mead, R., Kimani, C. W., Wachira, A. M. , Siamba D. N., \& Githinji, M. M., (2001b). Participatory strategic approach to development of improved indigenous poultry systems in East Africa. A paper presented at the International Development Conference, Rotorua, New Zealand 2-6 April 2001. [Online] Available: http://www.fao.org/docrep/019/aq634e/aq634e.pdf - 'The Bangladesh model and other experiences in family poultry development'. International Network for Family Poultry Development (INFPD) May-July 2002 and published in Global Journal of Agricultural Research Vol 1 No 2 pp 14-28 also [Online] Available: (http://www.eajournals.org/journals/global-journal-of-agricultural-research-gjar/vol-1-issue-2 -september-2013/)

Ndegwa, J. M, Norrish, P. Mead, R., Kimani, C. W., Wachira, A. M., (2002). Hatching characteristics of eggs artificially incubated from six reciprocal crosses of indigenous Kenyan chickens. Tropical Agriculture (Trinidad), Vol. 9 No 1.

Ndegwa, J. M, Norrish, P. Mead, R., Kimani, C. W., Wachira, A. M. (2005). Growth characteristics of indigenous chicken lines and a cross with Rhode Island Red in Kenya. Tropical Agriculture (Trinidad)) Vol 82 No 1

Ndegwa, J. M., (2006). Participatory research approaches in development of improved management practices in indigenous chicken production system with smallholder farmers in Kenya. PhD. Thesis, University of Reading, UK.

Ndegwa, J. M, Norrish, P. Mead, R., D. D. Shephered, Kimani, C. W., Wachira, A. M., (2012). Growth characteristics of six reciprocal crosses of Kenyan indigenous chickens Journal of 
Agricultural Science Vol 4 No.6.Pp 160-170.

Ndegwa, J. M. (2013 ed). Improving indigenous chicken production in Kenya-A livelihood strategy. LAP Lambert Academic Publishing https://www.lap-publishing.com/

Ndegwa, J. M, Norrish, P. Mead, R., D. D. Shephered, Kimani, C. W., Wachira, A. M., (2014). Investigating eggs hatchability in indigenous chicken system with smallholder farms in Kenya in a participatory research using analysis of variation. Journal of Applied Biosciences 80: 7000-7013.

Okali, C., Sumberg, J., \& Farrington, J., (1994). Farmer participatory research. Rhetoric and reality. Intermediate Technology publications London, UK: Overseas Development Institute.

Okong'o, Kabuage, L., Mbugua, P. N., \& Ndegwa, J. M., 1998. The effect of cooking grain amaranth (Amaranthus hypochodriacus) on its utilisation by broiler and indigenous chickens. In Proceedings of Rural Poultry Workshop. Kakamega, July 1998. Kenya

Pica-Ciamarra, V., \& Dhawan, M. (2010). Small-scale poultry farming and poverty reduction in South Asia: From good practices to good policies in Bangladesh, Bhutamn and India. New Delhi, South Asia pro-poor Livestock policy Programmes. [Online] Available: http//:sapplpp.org/lessonslearnt/smallscale-poultry-farming-and-poverty-reduction-in-south-a sia)

SA PPLPP, (2011). Proceedings of the Workshop in Bangladesh on "Implementation of the National Livestock Development Policy (2007) and National Livestock Development Policy (2008): Impact on Small-scale Livestock Rearers". [Online] Available: http//:sapplpp.org/files/repository/informationhub/workshop\%20proceedings20\%28Babglade sh\%205thApril\%202011.pdf.

Thieme, O., Sonaiya, E. B., Alders, R., Saleque M. A., \& De Besi, C. (2014). Family poultry development-Issues, Opportunities and Constraints. Animal Production and Health Working Paper No. 2. Rome (http//:www.fao.org/docrep/i019/i595e/i3595e.pdf).

Siamba, D. N., Ndegwa, J. M. Kimani, C. W., \& Mburu, B. M., (1998). Ethno-Veterinary practices among the Kikuyu in the Rift Valley Province in Kenya. In Proceedings of Rural Poultry Workshop. Kakamega, July 1998. Kenya Agricultural Research Institute (KARI) Kenya.

Sonaiya, E. B. (1990). Rural Poultry in Africa. Proceedings of the International Workshop, Obafemi Awolowo University, Ile-Ife, Nigeria, 13-16 November 1998. Ile-Ife, Nigeria, Thelia House Ltd.

Tuitoek, J. K., Chemjor, W., Ndegwa, J. M., \& Ottaro, J. M., (1999). Morphological characteristics and protein requirements of indigenous Kenyan chicken. In Proceedings of the 6th biennial Kenya Agricultural Research Institute (KARI) scientific conference 


\section{Copyright Disclaimer} 2015, Vol. 3, No. 2

Copyright for this article is retained by the author(s), with first publication rights granted to the journal.

This is an open-access article distributed under the terms and conditions of the Creative Commons Attribution license (http://creativecommons.org/licenses/by/3.0/). 